\title{
Optimalisasi Peran Mahasiswa Pendamping Program Upsus Pajale untuk Mempercepat Introduksi Teknologi Budidaya Jajar Lewogo Super di Kabupaten Sijunjung
}

\author{
Siska Efendi \\ Universitas Andalas \\ Corresponding author: siskaefendi@agr.unand.ac.id
}

\begin{abstract}
ABSTRAK
Fakultas Pertanian Universitas Andalas adalah salah satu mitra pemerintah dalam menyukseskan pelaksanaan Program Khusus (Upsus) Padi, Jagung, dan Kedelai (Pajale) khususnya di Provinsi Sumatera Barat. Pada tahun 2017 pelaksanaan Upsus Pajale di Sumatera Barat terdapat di delapan kabupaten dan kota salah satunya Kabupaten Sijunjung. Mahasiswa bersama alumni bertugas sebagai pendamping pelaksanaan beberapa program Upsus Pajale. Berbeda dengan pelaksanaan Upsus Pajale tahun 2015 dan 2016, pada tahun 2017 terdapat kegiatan penerapan teknologi di wilayah kerja mahasiswa pendamping. Teknologi yang diintroduksi dosen pendamping lapangan (DPL) bersama dengan mahasiswa pendamping adalah budidaya padi metode jajar legowo super. Penerapan teknologi tersebut dilaksakan di tiga kecamatan di Kabupaten Sijunjung yaitu Kecamatan Sijunjung, Tanjung Gadang dan Kamang Baru. Kegiatan dilakukan dalam bentuk demonstrasi plot (demplot) di lahan kelompok tani mitra. Teknologi budidaya jajar legowo berhasil diintroduksi kepada kelompok tani mitra yang ditandai dengan peningkatan hasil. Hasil menunjukkan bahwa terdapat peningkatan produktivitas padi dengan menggunakan metode jajar legowo super yaitu 4,6 ton/ha sampai 5,2 ton/ha dibandingkan dengan metode konvensional hanya 1,7-2 ton/ha.
\end{abstract}

Kata Kunci: beras; gabah; swasembada pangan; varietas unggul baru

\begin{abstract}
The Faculty of Agriculture of Andalas University is one of the government's partners in the successful implementation of Rice, Corn and Soybean (Upsus) Program at special province of West Sumatra. The implementation of Upsus Pajale in West Sumatra was found in eight districts and cities on 2017, one of which was Sijunjung Regency. Students and alumni participated as a companion in the implementation of several Upsus Pajale programs. In contrast to the implementation of Upsus Pajale in 2015 and 2016, in 2017, there were activities in applying technology in the work area of the accompanying students. The technology introduced by the field assistant lecturer together with the accompanying students, is the cultivation of Jajar Legowo super. The application of this technology was implemented in three sub-districts in Sijunjung Regency, namely Sijunjung, Tanjung Gadang and Kamang Baru. The activity was carried out in the form of a demonstration plot on the partner farmer's group's land. The technology of jajar legowo super has been successfully introduced to partner farmer groups, which is marked by increased production. The results showed that there was an increase in rice productivity using the Jajar Legowo Super method up to 4.6 tons / ha to 5.2 tons / ha than the conventional method of only 1.7-2 tons / ha.
\end{abstract}

Keywords: rice; grain; food self-sufficiency; new varieties

\section{PENDAHULUAN}

Upaya khusus (Upsus) padi, jagung, dan kedelai (Pajale) adalah salah satu upaya pemerintah untuk mempercepat tercapainya swasembada pangan tahun 2019. Pencapaian swasembada berkelanjutan padi dan jagung serta kedelai harus dicapai dalam waktu 3 (tiga) tahun. Swasembada pangan akan tercapai jika tahun 2015 produksi padi sebesar 73,40 juta ton, jagung sebesar 20,33 juta ton dan kedelai sebesar 1,27 juta. Untuk mempercepat tercapainya 
target tersebut maka pelaksanaan Upsus Pajale melibatkan banyak instansi dan pihak baik di tingkat pusat atau daerah. Penyuluh, mahasiswa/alumni dan Babinsa merupakan salah satu faktor penggerak bagi para petani dan dapat berperan aktif sebagai komunikator, fasilitator, advisor, motivator, edukator, organisator dan dinamisator dalam rangka terlaksananya kegiatan Upsus peningkatan produksi padi, jagung dan kedelai (Kementeri Pertanian, 2015). Selain itu penyuluh, mahasiswa dan Babinsa menjadi unsur penting dalam menggerakkan para petani pelaku utama untuk dapat menerapkan teknologi budidaya yang dapat mempercepat tercapainya swasembada pangan.

Budidaya padi jajar legowo super (Jarwo Super) adalah teknologi yang diintroduksi kepada petani di Kabupaten Sijunjung, Sumatera Barat. Produksi padi di Kabupaten Sijunjung dari tahun ke tahun masih fluktuatif. Peningkatan produktivitas atau hasil per hektar padi terus diupayakan dari waktu ke waktu. Pada periode 2012-2016 produktivitas padi di Kabupaten Sijunjung cenderung menurun yakni 78,3 ku/ha pada tahun 2011 turun menjadi 46,56 $\mathrm{ku} / \mathrm{ha}$ atau turun sebesar 40,64\%. Pemanfaatan teknologi budidaya berpeluang menjadi daya ungkit utama peningkatan produksi dan produktivitas padi. Teknologi budidaya terkini yang dapat diaplikasikan untuk meningkatkan produktivitas padi adalah sistem tanam legowo (Witjaksono, 2018). Teknologi jajar legowo super merupakan teknologi budi daya terpadu padi sawah berbasis tanam jajar legowo 2:1 untuk meningkatkan produktivitas (Priatmojo et al, 2019). Komponen penting dari teknologi Jarwo Super adalah: 1) varietas unggul baru padi potensi hasil tinggi; 2) biodekomposer yang diberikan bersamaan pada saat pengolahan tanah (bajak kedua); 3) pupuk hayati diaplikasikan melalui seed treatment dan pemupukan berimbang berdasarkan perangkat uji tanah sawah (PUTS); 4) pengendalian organisme pengganggu tanaman (OPT) menggunakan pestisida nabati dan pestisida sintetik berdasarkan ambang kendali; dan 5) alat-mesin pertanian (Balitbangtan, 2016). Penerapan teknologi jarwo super diyakini mampu memberikan hasil minimal 10 ton GKG/ha per musim, sementara hasil padi yang diusahakan dengan sistem jajar legowo hanya 6 ton GKG/ha. Dengan demikian terdapat penambahan produktivitas padi sebesar 4 ton GKG/ha per musim.
Rakitan teknologi budidaya jajar legowo super diintroduksi dengan metode demontrasion plot (demplot). Demplot adalah salah satu pendekatan yang banyak digunakan untuk mempercepat introduksi suatu inovasi kepada petani. Hal yang sama sebelumnya juga dilaporkan Hindersah et al. (2016) bahwa beberapa metode untuk mengintroduksi hasil penelitian ke dalam praktek pertanian sesungguhnya di tingkat petani. Jika dibandingkan dengan metode penyuluhan dan Focus Group Discussion (FGD) maka metode tersebut jauh lebih efektif (Alawiyah dan Cahyono, 2018). Pada pendekatan demplot petani ditempatkan sebagai subjek pelaksanaan kegiatan. Ditambahkan (Alawiyah dan Cahyono, 2018) pada kegiatan demplot petani dilibatkan secara langsung pada semua tahap kegiatan di lapangan. Pada percobaan sendiri petani dapat terlibat secara langsung semua kegiatan selama proses usahatani dan petani percaya pada apa yang telah dilakukannya sendiri karena dapat mengetahui kekurangan dan kelebihan yang ada pada tanaman budidaya, sehingga pengalaman tersebut dapat dijadikan sebagai pembelajaran musim tanam berikutnya.

Dosen dan mahasiswa/alumni memposisikan peran sebagai pendamping pelaksanaan kegiatan di lokasi demplot. Selain itu pada kegiatan demplot juga melibatkan berbagai pihak terkait. Seperti UPTD BPP, PPL, Babinsa, dan kelompok tani mitra. Keterlibatan pihak tersebut meningkatkan kepercayaan petani terhadap inovasi yang diintroduksi. Diadopsinya inovasi merupakan cerminan dari adanya proses perubahan sikap, pengetahuan dan keterampilan petani. Selain itu keberhasilan kegiatan demplot disebarluaskan oleh pihak yang terlibat ke berbagai nagari di Kabupaten Sijunjung. Setidaknya melalui demplot akan ada perubahan pengetahuan, opini, aspirasi dan keterampilan yaitu perubahan perilaku terendah setelah program intervensi (Radhakrishna, 2010). Penerapan teknologi bertujuan untuk mempercepat introduksi teknologi budidaya jajar legowo super (Jarwo Super) kepada masyarakat di Kabupaten Sijunjung melalui pendampingan mahasiswa dan alumni program Upsus Pajale

\section{METODE}

\section{Sosialisasi pelaksanaan demplot}

Sosialisasi dilakukan bersamaan acara serah terima mahasiswa/alumni pendamping 
program Upsus Pajale di Kantor Dinas Pertanian Kabupaten Sijunjung. Pada acara tersebut kepada Kelapa Dinas Pertanian Sijunjung menyampaikan bahwa salah satu kegiatan Upsus Pajale tahun 2017 adalah demplot penerapan teknologi. Kepala dinas merespon positif kegiatan tersebut dan menginstruksikan kepada kepala Unit Pelaksana Teknis Daerah Balai Penyuluh Pertanian (UPTD BPP) dan Penyuluh Petani Lapangan (PPL) untuk memfasilitas pelaksanaan kegiatan tersebut. Menindaklanjuti hal tersebut kepala UPTD BPP Kecamatan Sijunjung, Tanjung Gadang, dan Kamang Baru melakukan sosialisasi di unit kerja masingmasing. Pada acara tersebut kepala UPTD BPP mengundang PPL yang bertugas di kecamatan tersebut dan kelompok tani yang terdapat di masing-masing kecamatan.

Dosen DPL menjadi narasumber pada acara sosialisasi tersebut. Kepada peserta disampaikan sistematika pelaksanaan demplot jarwo super, mulai dari jadwal pelaksanaan, kriteria lokasi demplot, mitra kegiatan dan pengadaan bahan dan peralatan. Pada sesi akhir ditawarkan kepada petani yang bersedia mengizinkan lahan mereka sebagai lokasi demplot, sebagian besar petani yang hadir bersedia menggunakan lahan mereka untuk demplot. Setelah didiskusikan bersama kepala UPTD BPP, PPL, dan Mahasiswa/alumni maka ditetapkan demplot dilaksanakan di dua nagari di Kecamatan Tanjung Gadang yakni Nagari Sinyamu dan Timbulan. Di Nagari Sinyamu lahan yang digunakan adalah milik ibu Tin anggota Kelompok Tani Subur sedangkan di Nagari Timbulan lahan milik bapak Darisman anggota Kelompok Tani Tandikat. Luas demplot di kedua nagari tersebut sama yakni 0,25 ha. Untuk Kecamatan Sijunjung kegiatan demplot hanya dilakukan pada satu lokasi yakni di Nagari Padang Ranah. Walaupun demplot hanya dilakukan pada satu nagari akan tetapi luas lahan untuk demplot yakni 0,5 ha.

\section{Survei lokasi demplot}

Survei dilakukan satu minggu sebelum kegiatan demplot dimulai. Bertujuan untuk melihat kondisi lahan dan persiapan pembersihan dan pengolahan tanah. Survei dilakukan mahasiswa/alumni pendamping bersama kepala UPTD BPP, PPL, dan ketua kelompok tani pemilik lahan. Pada saat di lokasi dilakukan pengamatan luas lahan, kondisi saluran irigasi, riwayat penggunaan lahan, hama dan penyakit yang sebelumnya menyerang pada lokasi tersebut. Informasi tersebut diperoleh dengan diskusi langsung dengan petani pemilik lahan. Berdasarkan pengamatan dan diskusi maka ditetapkan bahwa lokasi tersebut sesuai untuk pelaksanaan demplot.

\section{Analisis tanah bersama PPL}

Bersamaan dengan survei lokasi demplot, juga dilakukan pengambilan sampel tanah untuk mengetahui tingkat kesuburan. Berdasarkan hasil analisis tersebut ditentukan dosis pemupukan yang akan dilakukan. Sampel tanah diambil sebanyak 1-2 kg, titik pengambilan sampel dengan metode garis diagonal sehingga didapatkan lima titik sampel. Analisis tanah masih menjadi hal yang baru bagi mahasisa/alumni pendamping Upsus sehingga untuk kegiatan tersebut dilakukan PPL di lokasi kegiatan (Gambar 1). Sampel tanah dibawa ke UPTD BPP untuk dilakukan analisis.

\section{Pengadaan komponen teknologi budidaya jarwo super}

Pengadaan bahan dan perlengkapan penerapan teknologi dilakukan DPL menggunakan dana hibah dari Kementerian Pertanian. Beberapa komponen teknologi jarwo super adalah varietas unggul baru (VUB), dekomposer M-Dec, pupuk hayati Agrimeth, dan pestisida nabati Bio-Protector, penggunaan mekanisasi pertanian berupa mesin tanam (jarwo transplanter) dan panen (Combine Harvester). Berdasarkan hasil diskusi dengan Badan Pengkajian Teknologi Pertanian (BPTP) Provinsi Sumetara Barat, direkomendasikan varietas Inpari Batipuh. Berbeda dengan beberapa provinsi lain di Sumatera, dilaporkan Priatmojo et al. (2019) bahwa petani di Aceh lebih banyak menggunakan varietas Inpara-32 sedangkan di Sumatera Utara lebih banyak menggunakan menanam varietas Inpari 33, dan di Sumatera Selatan sebagian besar menanam varietas Inpari 30. Masing-masing daerah menggunakan VUB yang berbeda, hal yang mendasari adalah kesesuaian kondisi daerah dan selera masyarakat. Dekomposer M-Dec dan pupuk hayati Agrimeth diperoleh dari Balai Penelitian Tanah (Balittanah) sedangkan BioProtector diperoleh dari Balai Penelitian Tanaman Rempah dan Obat (Balittro). Perlengkapan tersebut diserahkan kepada ketua kelompok tani sebelum kegiatan demplot dilaksanakan (Gambar 1). 


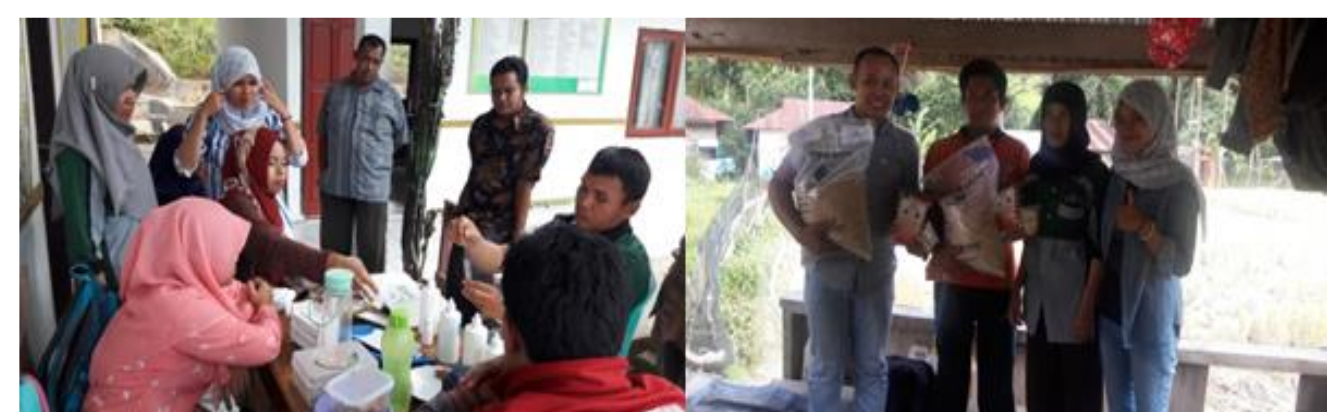

Gambar 1. Analisis tanah oleh mahasiswa/alumni bersama PPL (kiri) dan penyerahan saprodi kepada kelompok tani mitra (kanan)

\section{HASIL DAN PEMBAHASAN}

\section{Penyiapan Lahan}

Persiapan lahan diawali dengan pembersihan gulma dan sisa tunggul yang belum melapuk. Sebelum pembajakan dimulai, lahan digenangi terlebih dahulu sampai kedalaman 6$15 \mathrm{~cm}$. Pembajakan dilakukan dengan menggunakan hand tractor. Pembajakan pertama dengan bajak singkal sampai ke dalam $15-20 \mathrm{~cm}$, setelah olah tanah pertama dilakukan, lahan diinkubasi selama 3-4 hari. Berikutnya dilanjutkan olah tanah kedua menggunakan gelebek untuk memecah bongkahan tanah yang besar. Tahap terakhir persiapan lahan adalah pelumpuran menggunakan garu atau papan yang ditarik dengan traktor. Perbaikan dan pembuatan pematang dilakukan bersamaan dengan persiapan lahan. Dimana pematang sawah dibuat dengan lebar $35 \mathrm{~cm}$ dan tinggi $15-25 \mathrm{~cm}$. Gulma yang terdapat pada pematang dibersihkan dengan cangkul. Untuk mencegah gulma tidak tumbuh kembali maka pematang ditutupi dengan lumpur sedemikian rupa. Hal tersebut juga berfungsi untuk mencegah kebocoran.

\section{Aplikasi Pupuk Biodekomposer M.Dec}

Biodekomposer M.Dec berfungsi sebagai perombak bahan organik, berupa jerami sisa panen dan tunggul padi. Selama ini kebiasaan petani adalah membakar jerami sisa panen untuk mempercepat pengelolaan dan menghemat biaya. Tunggul padi sisa panen tergolong tinggi yakni $13-18 \mathrm{~cm}$. Kondisi ini akan mempersulit proses pembajakan. Biodekomposer M.Dec diaplikasikan 2 - $4 \mathrm{~kg} / \mathrm{ha}$ untuk mendekomposisi 2 - 4 ton jerami segar yang dicampur secara merata dengan 400 liter air bersih (Gambar 2). Setelah itu larutan biodekomposer disemprotkan secara merata pada tunggul dan jerami pada petakan sawah, tanah dibiarkan dalam kondisi lembap dan tidak tergenang minimal 7 hari.
Jerami dan tunggul padi akan melapuk dalam 15 hari setelah penyemprotan. Hal ini lebih baik dibandingkan yang dilaporkan Hutapea et al. (2018) bahwa pengomposan jerami menggunakan biodekomposer yakni 3 - 4 minggu. Ditambahkan Hutapea et al. (2018) bahwa hasil aplikasi biodekomposer mempercepat perombakan jerami dan mengubah residu organik menjadi bahan organik tanah, meningkatkan ketersediaan NPK, sehingga menekan biaya pemupukan, dan menekan penyakit tular tanah.

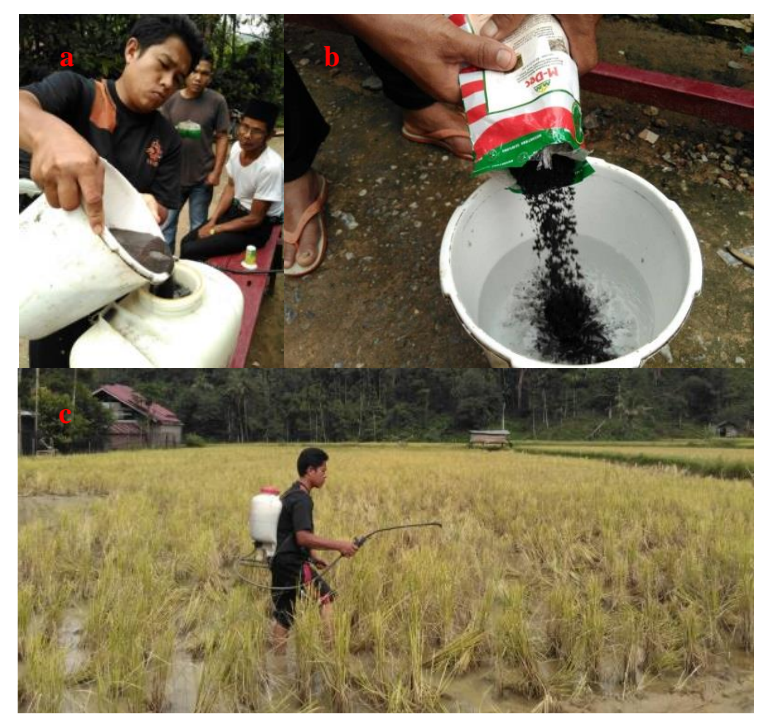

Gambar 2. (a.b) pembuatan larutan semprot, (c) aplikasi biodekomposer M-Dec

\section{Aplikasi Pupuk Hayati Agrimeth}

Pupuk hayati Agrimeth diaplikasikan hanya satu kali, yakni pada saat benih akan disemai, dengan cara sebagai berikut (1) Benih padi yang telah direndam dan diperam selama 24 jam, kemudian ditiriskan (kondisi lembap) kemudian dicampur dengan pupuk Agrimeth, (2) Pencampuran benih dengan pupuk Agrimeth dilakukan di tempat yang teduh, (3) Benih padi yang telah dicampur pupuk Agrimeth segera 
disemai, upayakan tidak ditunda lebih dari 3 jam dan tidak terkena paparan sinar matahari agar tidak mematikan mikroba yang telah melekat pada permukaan benih, (4) Sisa pupuk Agrimeth yang tidak melekat pada benih padi disebarkan di persemaian, dan (5) Benih yang telah terselimuti pupuk hayati disebar di persemaian pada kondisi tidak hujan.

\section{Persemaian}

Persemaian dilakukan dengan metode yang umum dilakukan petani (Gambar 3). Bila menggunakan persemaian biasa, benih padi yang telah direndam dan diperam selama 24 jam dan telah diaplikasi pupuk hayati langsung disebar merata di persemaian. Persemaian dilakukan pada salah satu sisi lahan sawah yang sudah siap dibajak dengan ukuran $8 \mathrm{~m}$ x $8 \mathrm{~m}$. Setelah dibajak lahan untuk persemaian dilumpurkan, kemudian dibagi menjadi dua petak yang masing-masing berukuran $8 \begin{array}{lllll} & 8 & \mathrm{x} & 2 & \mathrm{~m}\end{array}$ Persemaian dipasang waring untuk mencegah hama atau hewan lain yang akan mengganggu proses pembibitan. Air pada persemaian dikeringkan sampai pada kondisi macak-macak. Benih yang sudah diberi perlakuan Agrimeth ditebarkan pada persemaian yang sudah disiapkan. Berbeda dengan yang dilakukan petani di Oku Timur menggunakan penyemaian sistem dapog (200-230 kotak dapog)/ha (Hutapea et al., 2018). Kegiatan persemaian dilakukan kelompok tani didampingi PPL dan mahasiswa/alumni. Benih yang digunakan sebanyak $\quad 8 \quad \mathrm{~kg}$ untuk kebutuhan $1 / 4$ ha. Dilaporkan Priatmojo et al. (2019) bahwa pemakaian benih untuk sistem jarwo super berkisar antara $25-30 \mathrm{~kg} / \mathrm{ha}$. Pada kegiatan ini jumlah benih yang digunakan sengaja dilebihkan sebagai penyulam untuk benih yang rusak akibat serangan keong mas.

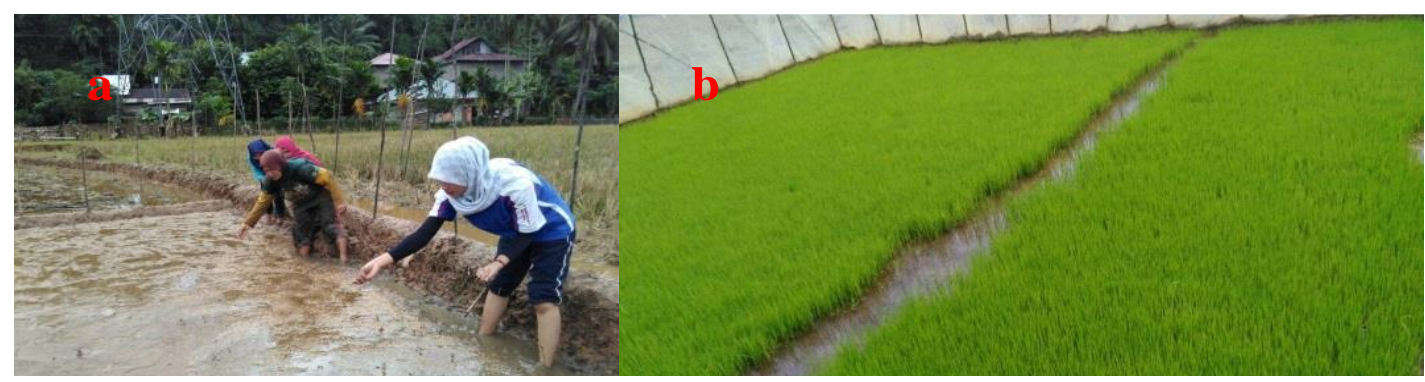

Gambar 3. (a) Penyemaian benih, dan (b) benih berumur 18 hari setelah semai

\section{Penanaman dan Penyulaman}

Penanaman dilakukan satu minggu setelah lahan disiapkan dan benih sudah berumur 18-21 hari (Gambar 4). Penanaman dilakukan kelompok tani mitra bersama dengan mahasiswa dan PPL. Sebelum lahan ditanami terlebih dahulu lahan dikeringkan sampai kondisi macakmacak. Hal tersebut bertujuan untuk memudahkan penanaman dan pencaplakan. Penanaman dilakukan anggota kelompok tani mitra sebanyak 6 orang dan dilakukan secara manual. Pada saat penanaman turut hadir Babinsa yang ditugaskan di lokasi kegiatan. Kepala UPTD BPP Kecamatan Tanjung Gadang juga ikut menanam pada lokasi demplot. Keterlibatan banyak pihak dalam kegiatan ini memberikan indikasi bahwa tingginya respon dari berbagai pihak terkait. Kondisi ini diharapkan dapat mempercepat introduksi teknologi jajar legowo super di Kabupaten Sijunjung.

Untuk memudahkan proses penanaman sebelumnya dilakukan pencaplakan. Pencapla- kan dilakukan untuk membuat tanda jarak tanam yang seragam dan teratur. Ukuran caplak menentukan jarak tanam dan populasi tanaman per satuan luas. Jarak antar baris dibuat $25 \mathrm{~cm}$, kemudian antar dua barisan dikosongkan $50 \mathrm{~cm}$. Jarak tanam dalam barisan dibuat sama dengan setengah jarak tanam antar baris $(12,5 \mathrm{~cm})$. Hal yang sama juga dilaporkan Priatmojo et al. (2019) petani jarwo super di Aceh, Sumatera Utara, dan Sumatera Selatan menggunakan jarak tanam $25 \mathrm{~cm} \times 12,5 \mathrm{~cm} \times 50 \mathrm{~cm}$.

Pola yang digunakan adalah jajar legowo 2:1. Pada tahap penanaman terlihat salah satu kekurangan dari teknologi jarwo super adalah membutuhkan tenaga kerja yang lebih banyak. Sebelumnya hal yang sama juga dilaporkan Priatmojo et al., (2019) dimana penerapan sistem tanam jajar legowo super memerlukan tambahan biaya tenaga kerja pada saat tanam. Untuk mengantisipasi hal tersebut maka penanaman direkomendasikan menggunakan mesin tanam jarwo transplanter. Hanya saja UPTD BPP dan kelompok tani mitra belum memiliki mesin 
tersebut. Tanam dengan cara manual menggunakan bibit muda dan ditanam 2-3 batang per rumpun.

Pada lokasi demplot di Nagari Sinyamu dan Timbulun dilakukan penyulaman sampai dua kali. Hal tersebut disebabkan hujan lebat setelah tanam membuat lahan tergenang. Beberapa bibit terangkut aliran banjir dan lebih parah kerusakan akibat serangan keong mas selama lahan tergenang. Penyulaman dilakukan menggunakan bibit yang sudah disiapkan pada persemaian. Penyulaman dilakukan kelompok tani mitra bersama dengan mahasiswa/alumni. Penyulaman harus selesai dua minggu setelah tanam (MST), atau sebelum pemupukan dasar. Hal yang sama juga dilaporkan Hutapea et al., (2018) bahwa penyulaman harus selesai paling lama dua minggu setelah tanam.

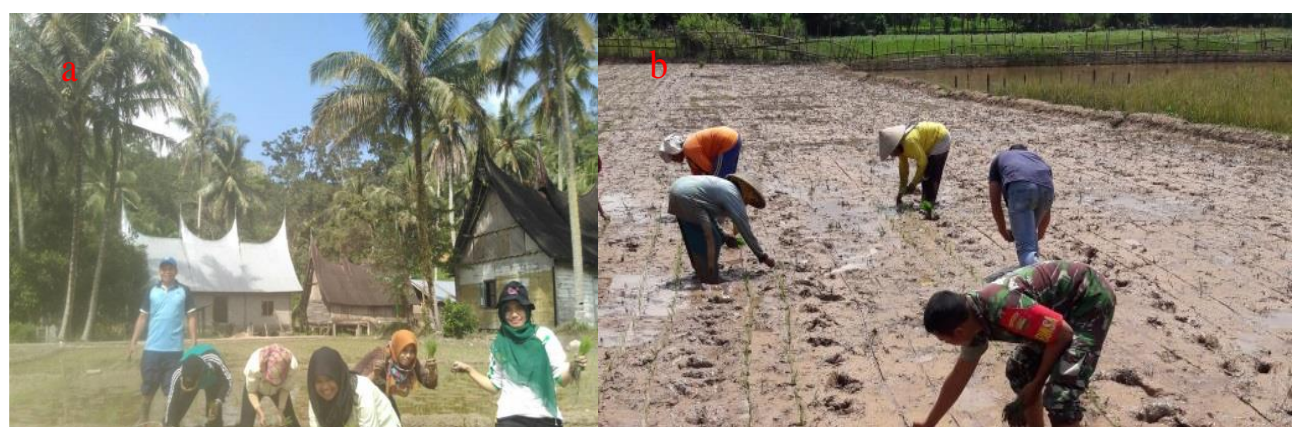

Gambar 4. Penanaman (a) Nagari Sinyamu, (b) Nagari Sijunjung

\section{Pengairan}

Salah satu permasalahan yang umum dihadapi petani di Kabupaten Sijunjung adalah ketersediaan air termasuk di lokasi kegiatan. Di lokasi demplot belum tersedia saluran irigasi permanen sehingga manajemen pengairan tidak bisa dilakukan dengan baik. Selain itu kebiasaan petani di lokasi kegiatan adalah menggenangi lahan setelah penanaman. Hal tersebut mereka lakukan untuk mengantisipasi kalau tidak terjadi hujan beberapa bulan ke depan. Padahal lahan sawah tidak boleh digenangi satu minggu setelah penanaman agar proses pembentukan anakan tidak terganggu. Sehingga alternatif solusinya adalah dengan membuat saluran pemasukan dan pembuangan. Tinggi muka air $3-5 \mathrm{~cm}$ harus dipertahankan mulai dari pertengahan pembentukan anakan hingga satu minggu menjelang panen untuk mendukung periode pertumbuhan aktif tanaman. Saat pemupukan, kondisi air dalam keadaan macak-macak. Untuk mengontrol kondisi air di lokasi demplot dilakukan mahasiswa pendamping secara bergantian.

\section{Penyiangan}

Penyiangan gulma dilakukan pada saat tanaman berumur 21 hari setelah tanam (HST) dan 42 HST. Penyiangan dilakukan secara manual dan mekanis menggunakan gasrok. Pelaksanaan waktu penyiangan diinformasikan terlebih dahulu kepada ketua kelompok tani mitra. Pada hari yang sudah ditentukan semua anggota kelompok tani mitra hadir pada kegiatan tersebut. Gulma yang tumbuh dicabut dengan tangan kemudian langsung dibenamkan ke dalam lumpur. Penyiangan juga dilakukan dengan menggunakan gasrok, walaupun alat ini tidak populer di kalangan masyarakat akan tetapi kelompok tani mitra sangat tertarik untuk menggunakan alat tersebut. Penggunaan alat penyiang tersebut tergolong mudah terutama pada pola tanam jarwo super.

\section{Pemupukan dengan Pupuk Sintetik}

Pertumbuhan padi di lokasi demplot dioptimalkan dengan pemupukan secara intensif. Sebelum dilakukan pemupukan terlebih dahulu dilakukan analisis tanah sawah dan analisis bagan warna daun. Analisis tanah sawah dilakukan PPL bersama dengan mahasiswa pendamping di kantor UPTD BPP Kecamatan Tanjung Gadang. Hal tersebut dilakukan agar pemupukan sesuai dengan kondisi terkini di lokasi demplot atau diistilahkan dengan pemupukan spesifik lokasi. UPTD BPP Kecamatan Tanjung Gadang sudah memiliki perangkat alat untuk melakukan analisis tanah sawah sebagai dasar menentukan kebutuhan pemupukan. Berdasarkan hasil analisis tanah sawah, diperoleh hasil bahwa aplikasi pupuk urea $200 \mathrm{~kg} / \mathrm{ha}$ dan NPK Phonska $300 \mathrm{~kg} / \mathrm{ha}$. Pupuk Phonska diaplikasikan $100 \%$ pada saat tanam dan pupuk urea masing-masing $1 / 3$ pada umur 7-10 HST, 1/3 bagian pada umur 25-30 HST, dan 1/3 bagian pada umur 40-45 HST 


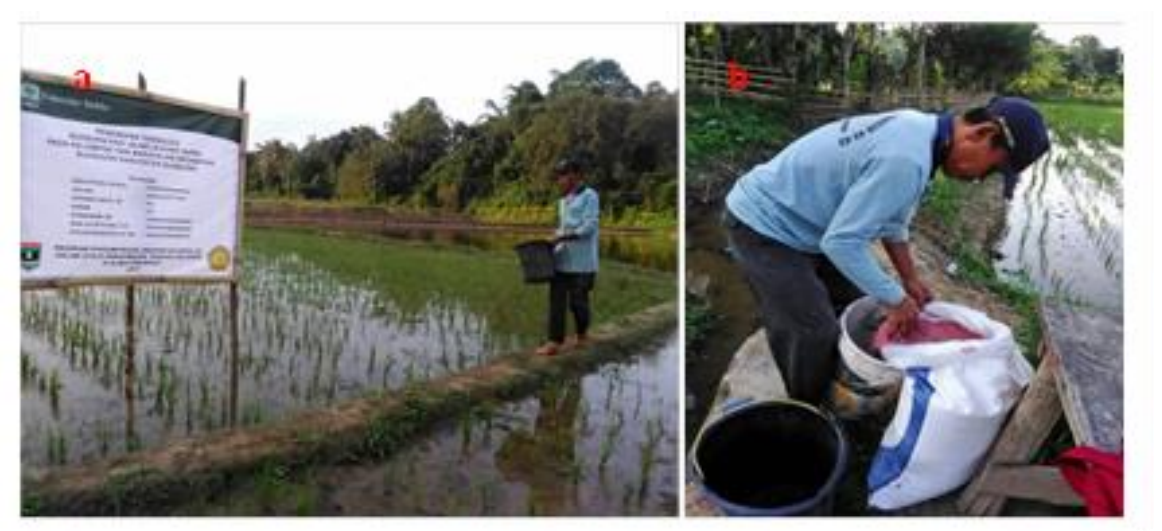

Gambar 5. Pemupukan pada lokasi demplot

Pengadaan pupuk menggunakan dana hibah dari Kementerian Pertanian sebagai paket pelaksanaan kegiatan penerapan teknologi. Berikutnya untuk pemupukan dilakukan kelompok tani mitra (Gambar 5). Pupuk yang digunakan adalah pupuk non subsidi hal ini berdasarkan permintaan dari kelompok tani mitra. Dimana masih terdapat anggapan bahwa kualitas pupuk non subsidi lebih baik dibandingkan subsidi. Pemikiran ini hampir ditemukan pada semua petani di lokasi demplot. Sebelum dilakukan pemupukan lahan digenangi sampai ketinggian 3-7 cm. Semua pintu keluar air ditutup untuk mencegah pupuk terangkur air kalau terjadi hujan. Pemupukan dilakukan 1-2 minggu setelah penyiangan.

\section{Panen}

Padi di lokasi demplot dipanen pada umur 110 sampai 120 hari (Gambar 6). Waktu panen tergolong lama karena varietas yang digunakan adalah Inpari 21 Batipuh yang umur panennya mencapai 120 hari. Kondisi tersebut tidak menjadi permasalahan oleh petani. Hal ini tidak terlepas dari ketahanan varietas tersebut terhadap penyakit tungro dan serangan hama keong mas. Padahal pada tahun 2017 beberapa nagari di Kecamatan Tanjung Gadang adalah endemik serangan tungro. Selama proses budidaya, OPT tersebut tidak ditemukan menyerang tanaman padi. Hal tersebut merupakan indikasi bahwa kegiatan demplot yang dilakukan dengan mengkombinasikan pola tanam jajar legowo super dan varietas unggul baru (VUB) berhasil menekan tingkat kerusakan yang disebabkan penyakit tungro.

Panen dilakukan pada saat tanaman matang fisiologis yang dapat diamati secara visual pada hamparan sawah, yaitu 90-95\% bulir telah menguning atau kadar air gabah berkisar 22-27\%. Padi yang dipanen pada kondisi tersebut menghasilkan gabah berkualitas baik dan rendemen giling yang tinggi. Panen di lokasi demplot dilakukan secara manual oleh kelompok tani mitra dengan menggunakan sabit. Batang padi dipotong pada ketinggian 7-10 $\mathrm{cm}$ dari permukaan tanah. Batang padi yang sudah dipotong diletakkan pada tunggul padi yang baru saja siap dipotong. Hal tersebut bertujuan agar bulir padi tidak menyentuh tanah dan kotor. Selain itu satu minggu sebelum panen lahan sudah dikeringkan. Batang padi yang sudah dipotong dikumpulkan untuk dirontokkan menggunakan mesin perontok. Selama ini sebagian besar petani di lokasi kegiatan masih menggunakan perontok tradisional yang disebut "pompe". Cara kerja alat tersebut adalah batang padi yang sudah dipotong dibantingkan ke permukaan pompe tersebut sampai bulir padi rontok. Penggunaan alat perontok tersebut tergolong sangat tidak efektif karena banyak bulir padi yang berserakan selama proses perontokan.

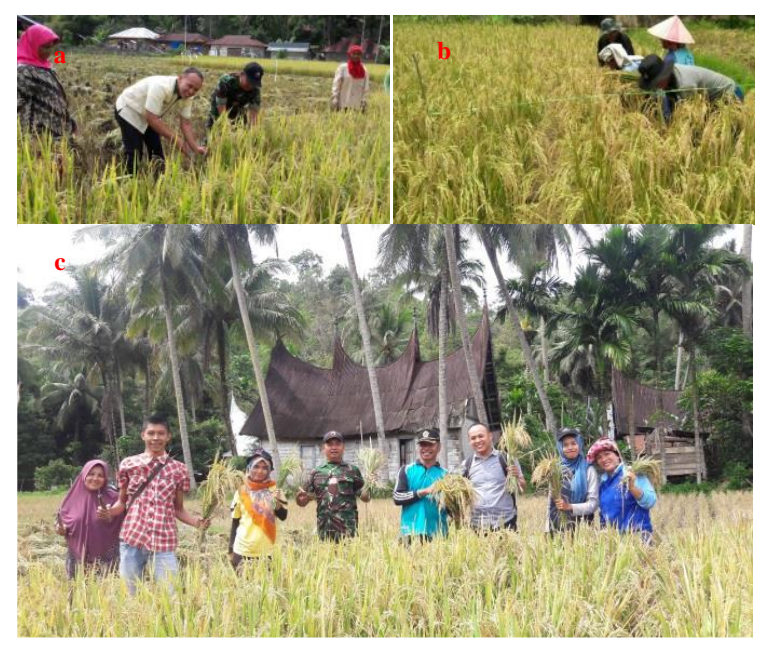

Gambar 6. Panen (a) Nagari Timbulun, (b) Nagari Sijunjung dan (c) Sinyamu 
Sebelum panen, dilakukan pengubinan untuk mendapatkan data produksi padi di lokasi kegiatan. Pengubinan dilakukan oleh Badan Pusat Statistik Kab. Sijunjung. Selain dihadiri BPS kegiatan panen di lokasi demplot juga dihari kepala UPTD BPP dan Babinsa serta mahasiswa pendamping. Produksi tertinggi terdapat di Nagari Sinyamu yakni 5,2 ton/ha dan Sijunjung yakni 5,2 ton. Produksi terendah terdapat di Nagari Timbulun. Walaupun berbeda hasil panen di lokasi demplot masih lebih tinggi dibandingkan yang dilaporkan Priatmojo et al. (2019) dimana produksi di Sumatera Selatan yang mencapai $2.172 \mathrm{~kg} / \mathrm{ha}$, kemudiaan diikuti oleh Aceh 1.726,04 kg/ha, dan Sumatera Utara $866,03 \mathrm{~kg} / \mathrm{ha}$. Teknologi budidaya padi jarwo yang diterapkan di Kabupaten Oku Timur menunjukkan adanya peningkatan produktivitas 20,78\% (Hutapea et al., 2018). Banyak penelitian telah menunjukkan bahwa sistem tanam jajar legowo dapat meningkatkan produktivitas sebesar $1-1,5$ ton/ha atau lebih dari 30 persen dibandingkan dengan metode tanam konvensional (Witjaksono, 2018). Hal ini merupakan daya tarik tersendiri bagi petani sekitarnya untuk mengikuti jarwo super ini.

\section{KESIMPULAN}

Penerapan teknologi budidaya jajar legowo seper pada tiga kecamatan di Kabupaten Sijunjung terlaksana dengan baik berkat kerjasama semua pihak dan pendampingan yang dilakukan mahasiswa/alumni program Upsus Pajale. Pendampingan pelaksanaan penerapan dilakukan mahasiswa/alumni pada semua rangkaian kegiatan demplot mulai dari sosialisasi, survei lokasi dempot, persiapan komponen jarwo super, sampai pelaksanaan demplot. Produksi padi di lokasi dempot yang mencapai 4,6-5,2 ton/ha merupakan bukti dari optimalnya pendampingan yang dilakukan mahasiswa/alumni. Keberhasilan kegiatan demplot jajar lewogo super akan mempercepat introduksi teknologi tersebut ke beberapa kecamatan lain di Kabupaten Sijunjung, Sumatera Barat. Pengembangan inovasi Jarwo Super di tingkat petani tidak terlepas dari mekanisme transformasi teknologi yang dilakukan mahasiswa/alumni.

\section{UCAPAN TERIMA KASIH}

Pelaksanaan penerapan teknologi sebagai bagian dari program Upsus Pajale dan Siwab di
Kab Sijunjung tidak terlepas dari bantuan dan kerja sama banyak pihak. Untuk itu kami mengucapkan terima kasih kepada Prof. Dr. Ir. Aswaldi Anwar, M.Si. selaku Ketua Pelaksana Upsus Pajale dan Siwab Universitas Andalas, Bapak Ronald selaku Kepala Dinas Pertanian, Ibu Ningwisma Utami S.P., M.Si. dan Ibu dr. Meli selaku Kepala Bagian Tanaman Pangan Dinas Pertanian Kab. Sijunjung. Bapak Rinaldi selaku kepala UPTD BPP Puskeswan Muaro Sijunjung, Bapak Jod Bay selaku kepala kepala UPTD BPP Kec. Sijunjung, Bapak Agus selaku kepala UPTD BPP Tanjung Gadang, Bapak Jhon Fernedi selaku kepala UPTD BPP Kamang Baru. Ucapan terima kasih juga untuk Penyuluh Petani Lapangan (PPL) Kecamatan Tanjung Gadang, Sijunjung, dan Kamang Baru, ketua kelompok tani dan petani yang terlibat pada pelaksanaan penerapan Teknologi.

\section{DAFTAR PUSTAKA}

Alawiyah, F. muna, \& Cahyono, E. dwi. (2018). Persepsi Petani Terhadap Introduksi Inovasi Agens Hayati Melalui Kombinasi Media Demplot dan FFD. Jurnal Ekonomi Pertanian dan Agribisnis, 2(1), 19-28. https://doi.org/10.21776/ub.jepa.2018.00 2.01.3

Balitbangtan. (2016). Petunjuk Teknis Budi Daya Padi Jajar Legowo. Kementerian Pertanian. Jakarta. Retrieved from http://tanamanpangan.pertanian.go.id/ass ets/front/uploads/document/Petunjuk\%20 teknis\%20Jarwo\%20Oke.pdf

Hindersah, H., Mutiarawati, T., Kuswaryan, S., Kalay, A. M., Talahaturuson, A., \& Risamasu, R. (2016). Penggunaan Demonstrasi Plot Untuk Mengubah Metode Aplikasi Pupuk Organik Pada Lahan Pertanian Sayuran Di Kota Ambon. Jurnal Aplikasi Iptks Untuk Masyarakat, 5(1), 9-15. Retrieved from http://jurnal.unpad.ac.id/dharmakarya/arti cle/view/8872

Hutapea, Y., Waluyo, W., \& Sasmita, P. (2018). Persepsi Petani dan Prospek Budidaya Padi Jajar Legowo Super di Oku Timur. Prosiding Seminar Nasional Teknologi Pertanian, O(0), 212-221. Retrieved from http://jurnal.polinela.ac.id/index.php/PR OSIDING/article/view/726/516

Kementerian Pertanian. (2015). Pedoman Pengawalan dan Pendampingan Terpadu Penyuluh, Mahasiswa, dan Bintara 
Pembina Desa dalam Rangka Upaya Khusus Peningkatan Produksi Padi, Jagung, dan Kedelai. Jakarta Retrieved from http://perundangan.pertanian.go.id/ admin/p_mentan/Permentan\%2014-2015 $\%$ 20Upaya\%20Khusus\%20Peningkatan $\% 20$ Produksi $\% 20$ Padi $\% 20 J a g u n g \% 20 \mathrm{Ke}$ delai.pdf

Priatmojo, B., Adnyana, M. O., Wardana, I. P., \& Sembiring, H. (2019). Kelayakan Finansial dan Teknis Cara Tanam Padi Jajar Legowo Super di Sentra Produksi Padi Kawasan Sumatera. Penelitian Pertanian Tanaman Pangan, 3(1), 9-15. http://dx.doi.org/10.21082/jpptp.v3n1.20 19.p9-15

Radhakrishna, R. (2010). Viewing Bennett's Hierarchy from a Different Lens: Implications for Extension Program Evaluation. Journal of Extension, 48(6), 1-5. Retrieved from https://joe.org/joe/ 2010december/tt1.php

Witjaksono, J. (2018). Kajian Sistem Tanam Jajar Legowo untuk Peningkatan Produktivitas Tanaman Padi di Sulawesi Tenggara. Pangan, 27(1), 1-8. Retrieved from https://jurnalpangan.com/index.php /pangan/article/view/400 